\title{
Pengembangan Produk Tabungan Dengan Akad Mudharabah Muthlaqah Di Bank Syariah Mandiri Kep Siliwangi Cirebon
}

\author{
Afif Muamar', Uswatun Khasanah², Diki Darmawan ${ }^{3}$ \\ IAIN Syekh Nurjati Cirebon, \\ 1 e-mail: afifmuamar85@gmail.com, \\ 2 e-mail: uswatun.attasshof@yahoo.com, \\ ${ }^{3}$ e-mail: james.dikdar11@gmail.com
}

\begin{abstract}
ABSTRAK
Penelitian ini bertujuan untuk menjelaskan produk-produk dalam Bank Syariah Mandiri dan mekanisme produk tabungan BSM dengan akad Mudharabah Muthlaqah. Oleh karena itu, penelitian ini menggunakan metode kualitatif deskriptif. Adapun hasil temuan dalam penelitian ini, yaitu pertama, ada tiga macam produk Bank Syariah Mandiri yang sampai saat ini masih beroperasi, yaitu produk penghimpunan dana, produk pembiayaan (penyaluran dana), dan produk pelayanan jasa Bank. Kedua, tabungan BSM merupakan tabungan harian yang menggunakan mata uang rupiah. Rekening ini berdasarkan sistem akad mudharabah muthlaqah dengan melalui alur, yaitu pembukaan rekening tabungan, penyetoran tabungan BSM dapat dilakukan diseluruh kantor Bank Syariah Mandiri sesuai jam buka kas, penarikan tunai diloket teller nasabah harus datang ke kantor Bank Syariah Mandiri, penutupan rekening tabungan BSM dilakukan dengan mengisi formulir yang telah disediakan, dan penggantian buku tabungan yang hilang diapat dilakukan dengan membuat surat surat kehilangan di kantor polisi terdekat kemudian menyerahkannya kepada customer service.
\end{abstract}

Kata Kunci: Produk Tabungan, Mudharabah Muthlaqah, dan Bank Syariah Mandiri

\begin{abstract}
This study aims to explain the products in Bank Syariah Mandiri and the mechanism of BSM savings products with the Mudharabah Muthlaqah contract. Therefore, this study uses descriptive qualitative methods. The findings in this study, namely, first, there are three types of Bank Syariah Mandiri products that are still operating, which are fundraising products, financing products (channeling funds), and Bank service products. And second, BSM savings are daily savings using the rupiah currency. This account is based on the mudharabah muthlaqah contract system through the channel, namely opening a savings account, depositing BSM savings can be done in all offices of Bank Syariah Mandiri in accordance with the opening hours of cash, cash withdrawals in the teller's skyline customers must come to the office of Bank Syariah Mandiri, closing the BSM savings account fill out the form provided, and the replacement of the lost savings book can be done by making a letter of loss at the nearest police station then submit it to customer service.
\end{abstract}

Keywords: Savings Products, Mudharabah Muthlaqah, and Bank Syariah Mandiri 


\section{PENDAHULUAN}

Pesatnya perkembangan bank syariah salah satunya dipengaruhi oleh hampir semua bank yang awalnya fokus pada bank konvensional mulai membuka Unit Usaha Syariah (kemudian disebut UUS) pada sistemnya yang mayoritas bank umum syariah juga memiliki induk pada bank konvensional. Banyaknya bank yang menerapkan sistem konvensional membuka UUS maupun bank umum syariah menunjukan pasar perbankan syariah di Indonesia masih sangat besar dan bisa berkembang dengan luas.

Eksistensi perbankan yang berlabel syariah di Indonesia ialah perwujudan atas keinginan warga masyarakat yang menginginkan suatu sistem dalam perbankan yang menerapkan prinsip syariah. Hal ini dimaksudkan agar persoalan bunga tidak lagi ada ditengah-tengah mereka, sehingga masyarakat tidak perlu merasa khawatir lagi atas persoalan bunga tersebut. Pertumbuhan suatu bank dipengaruhi dengan strategi dalam penghimpunan dana masyarakat, baik skala besar maupun kecil. Hal ini menunjukan bahwa permasalahan seputar pendanaan di bank adalah suatu masalah yang paling utama, sehingga bank tidak bisa berfungsi tanpa adanya dana yang cukup.

Kemudian, perlu dipaparkan juga bahwa saat ini produk tabungan merupakan simpanan yang diminati oleh masyarakat. Hal ini dikarenakan tabungan memiliki kemudahan secara prosedural, baik saat pembukaan rekening maupun pengambilan dana. Simpanan yang berbentuk tabungan juga merupakan sumber pendanaan bank yang penting, karena mudah didapat dari masyarakat. Menurut Wanto (2014), pada umumnya akad produk tabungan dapat terlihat dalam dua akad dalam sekali transaksi, yaitu akad mudharabah, sedangkan pada produk akadnya yang ada di buku tabungan utama/induk menggunakan akad wadi'ah. Dengan demikian, simpanan yang berbentuk tabungan adalah sumber pendanaan yang potensial untuk mempertahankan usaha dan meningkatkan sumber pendanaan bank. Keberhasilan suatu bank dalam menarik dana dari masyarakat disebabkan adanya kepercayaan dari masyarakat kepada bank yang terkait.

Inovasi produk telah disajikan, salah satunya Bank Syariah Mandiri (BSM) yang saat ini semakin maju dan pertumbuhannya semakin pesat. Salah satu produk tabungan atau investasi yaitu Tabungan BSM. Tabungan BSM ini memiliki fasilitas dan keunggulan yang dapat memenuhi kebutuhan nasabah. Sehingga produk tabungan ini bisa menarik minat nasabah dan menaruh kepercayaan masyarakat untuk menabung dan berinvestasi pada Bank Syariah Mandiri. Pada produk Tabungan di BSM KCP Siliwangi Cirebon menggunakan akad mudharabah mutlaqah.

Tabungan BSM merupakan suatu produk tabungan yang perkembanganya seiring dengan perkembangan perusahaan Bank Syariah Mandiri. Oleh karena itu, penelitian ini memiliki tujuan utama untuk mengetahui bagaimana produk-produk dalam Bank Syariah Mandiri sekaligus mekanisme produk tabungan BSM melalui jenis akad mudharabah muthlaqah. 


\section{BAHAN DAN METODE}

Penelitian ini menggukan metode kualitatif deskriptif, yaitu prosedur suatu penelitian untuk memperoleh data deskriptif berupa rumusan berbentuk tulisan atau pernyataan lisan dan perilaku orang-orang yang diamati (Moleong, 1997). Metode kualitatif dipergunakan untuk mengumpulkan data-data dari para informan terpilih dengan instrumen berupa pertanyaanpertanyaan yang disiapkan sebelumnya.

Adapun objek dalam penelitian ini, yaitu pertama, produk Tabungan BSM melalui jenis akad mudharabah muthlaqah. Dan kedua, proses transaksi Tabungan BSM yang menerapkan jenis akad mudharabah muthlaqah.Teknik mengumpulkan data yang dipergunakan di penelitian ini, yaitu sebagai berikut:

a. Metode Observasi

Observasi adalah suatu alat dalam mengumpulkan data-data pengamatan dan pencatatan secara sistemik gejala-gejala yang diselidiki. Observasi juga sebagai salah satu cara untuk mengamati dengan cara melakukan pengamatan terhadap objek yang akan diteliti (Narbuko \& Ahmadi, 2007). Oleh karena itu akan diterapkan observasi non partisipan untuk mendengarkan dan melihat situasi tertentu tanpa partisipasi aktif didalamnya (Emzir, 2012). Dalam istilah lain dikenal dengan observasi partisiatif pasif (Sugiyono, 2016). Observasi partisiatif pasif dilakukan dengan cara mengamati praktik mekanisme produk Tabungan BSM melalui Akad Mudharabah Muthlaqah di BSM KCP Siliwangi Cirebon.

b. Metode Wawancara

Wawancara merupakan suatu proses tanya jawab secara lisan dan bertatap muka untuk mendengarkan langsung berbagai informasi dan keterangan lebih lanjut (Narbuko \& Ahmadi, 2007). Melalui wawancara kali ini, peneliti bermaksud untuk mengetahui mekanisme produk Tabungan BSM melalui Akad Mudharabah Muthlaqah di BSM KCP Siliwangi Cirebon dengan Bapak Bahtiar selaku Customer Service sebagai informan.

c. Metode Dokumentasi

Dokumentasi merupakan kegiatan menyelidiki sumber-sumber yang terdapat disuatu dokumen sehingga diperoleh penjelasan yang diperlukan dalam suatu penelitian. Metode dokumentasi meliputi pengumpulan data dan penelaahan lebih lanjut atas catatan dan dokumen penelitian seperti halnya buku-buku mengenai produk tabungan atau simpanan serta akad mudharabah muthlaqah dan dokumen-dokumen yang peneliti peroleh dari BSM KCP Siliwangi Cirebon. 


\section{HASIL DAN PEMBAHASAN}

\section{Produk-produk yang Dikembangkan oleh Bank Syariah Mandiri (BSM)}

Ada tiga jenis produk di BSM yang sampai saat ini masih beroperasi, antara lain sebagai berikut:

1. Produk Penghimpunan Dana

Bank syariah memiliki fungsi yang pertama yaitu penghimpunan dana dari masyarakat. Bank syariah menghimpun dana yang berbentuk titipan dengan akad al-Wadi' ah dan investasi dengan akad al-Mudharabah. Al-Wadi'ah merupakan akad yang terjadi antara pihak masyarakat dengan pihak bank. Sedangkan al-Mudharabah yaitu suatu akad diantara pemilik dana yang menginvestasikan dananya (shahibul maal) dengan pihak bank yang menerima dana (mudharib) untuk dimanfaatkan dengan ketentuan yang dibolehkan oleh hukum Islam (Ismail, 2011).

a. Tabungan BSM

Tabungan BSM merupakan tabungan yang dalam praktik penarikan dan setorannya dilakukan kapan saja selama jam konter kas di BSM dibuka atau melalui ATM.

1) Aman dan terjamin.

2) Dapat dilakukan secara online pada seluruh outlet di BSM.

3) Menerapkan sistem bagi hasil yang kompetitif.

4) Fasilitas BSM Card memiliki fungsi sebagai ATM dan Debit.

5) Fasilitas e-Banking berupa BSM Mobile Banking dan BSM Net Banking.

6) BSM menerima layanan penyaluran zakat, infaq, dan sedekah.

Persyaratan: Kartu identitas berupa KTP/Paspor/SIM nasabah.

Karakteristik:

1) Prinsip syariah pada BSM dipraktikan dengan akad Mudharabah Mutlaqah.

2) Saldo minimum setoran Rp.80.000,-

3) Saldo minimum setoran selanjutnya Rp.10.000,-

4) Saldo minimum Rp.50.000,-

5) Biaya tutup rekening Rp.20.000,-

6) Biaya administrasi tiap bulan Rp.6.000,-

b. BSM TabunganKu

TabunganKu merupakan suatu tabungan yang diterbitkan oleh bank-bank di Indonesia secara bersamaan bagi pihak-pihak yang berkepentingan dengan persyaratan yang mudah dan ringan, serta bertujuan menumbuhkan budaya menabung dalam upaua meningkatkan kesejahteraan bagi masyarakat. 
Manfaat:

1) Terjamin keamanannya dan kemudahan mengakses secara online di outlet-outlet BSM di Indonesia.

2) Pihak bank menetapkan kebijakan bonus sesuai akad wadi'ah.

Persyaratan : Kartu identitas berupa KTP/Paspor/SIM nasabah.

Karakteristik :

1) Berdasarkan prinsip syariah dengan akad wadi' ah yad dhamanah.

2) Bebas biaya administrasi rekening.

3) Biaya pemeliharan Kartu TabunganKu Rp.2.000,- (bila ada).

4) Setoran awal minimum Rp.20.000,- dan selanjutnya Rp.10.000,-

5) Jumlah minimum saldo rekening (setelah penarikan) Rp.20.000,-

6) Biaya atas penutupan rekening sebesar Rp.20.000,- jika atas permintaan nasabah.

7) Saldo minimum melakukan penarikan di counter, Rp.100.000,- kecuali saat tutup rekening.

8) Rekening dorman (jika tidak melakukan transaksi selama 6 bulan berturut-turut).

9) Biaya penalty Rp.2.000,- per bulan.

10) Apabila jumlah saldo dalam rekening mencapai < Rp.20.000,- maka sistem dengan sendiri akan menutup rekening tersebut dengan biaya penutupan rekening sesuai jumlah sisa saldo yang ada.

c. BSM Simpatik

BSM Simpatik menetapkan tabungan sesuai prinsip akad wadi' ah, dan dapat melakukan penarikan dilakukan berdasarkan syarat-syarat yang disepakati disetiap waktu.

Manfaat :

1) Terjamin keamanannya.

2) Kemudahan mengakses secara online di outlet-outlet BSM di Indonesia.

3) Kebijakan BSM memberikan bonus bulanan terhadap nasabah.

4) Memperoleh fasilitas e-Banking berupa BSM Net dan BSM Mobile Banking.

5) Dapat membantu menyalurkan zakat, infaq, dan sedekah dari nasabah.

Persyaratan: Kartu identitas berupa KTP/Paspor/SIM nasabah.

Karakteristik :

1) Menerapkan prinsip syariah melalui akad wadi'ah.

2) Setoran awal minimal Rp.20.000,- (tanpa ATM) \& Rp.80.000,- (dengan ATM)

3) Setoran berikutnya minimal Rp.10.000,-

4) Saldo minimal Rp.20.000,- 
5) Biaya administrasi Rp2.0000 (tanpa ATM) \& Rp30.000 (dengan ATM).

d. BSM Tabungan Berencana

Tabungan berencana yaitu tabungan berjangka yang menghasilkan nisbah bagi hasil yang berjenjang dan kepastian dalam mencapai target dana yang ditetapkan.

Manfaat tabungan :

1) Memperoleh bagi hasil yang kompetitif.

2) Mempermudah nasabah membuat perencanaan keuangan dalam jangka panjang.

3) Perlindungan berupa asuransi bagi nasabah secara gratis dan otomatis.

4) Jaminan pencapaian target dana.

e. BSM Tabungan Investa Cendekia

Tabungan jenis ini merupakan tabungan berjangka dalam keperluan uang pendidikan yang disetorkan secara tetap pada tiap bulannya dan dilengkapi dengan asuransi untuk melindungi pihak nasabah.

Manfaat:

1) Memperoleh bagi hasil yang kompetitif.

2) Mempermudah nasabah membuat perencanaan keuangan, khususnya pendidikan putra/putri.

3) Perlindungan berupa asuransi bagi nasabah secara gratis dan otomatis.

f. Tabungan Mabrur

Tabungan mabrur merupakan jenis tabungan yang membantu para nasabah dalam melaksanakan ibadah haji dan umrah di Tanah Suci.

Manfaat:

1) Amanan dan terjamin.

2) Mendapatkan porsi haji bagi para nasabah melalui fasilitas talangan haji.

3) Pendaftaran haji dipermudah melalui online di SISKOHAT Kementerian Agama.

Persyaratan: Kartu identitas berupa KTP/Paspor/SIM nasabah.

Karakteristik :

1) Menerapkan prinsip syariah dengan akad mudharabah muthlaqah.

2) Tabungan tidak dapat dicairkan, kecuali untuk melunasi Biaya Penyelenggaraan Ibadah Haji/Umrah.

3) Setoran awal minimal Rp.500.000,-

4) Setoran selanjutnya minimal Rp.100.000,-

5) Pendaftran di SISKOHAT dengan saldo minimum Rp.25.100.000,-

6) Penutupan rekening untuk pembatalan dikenakan biaya Rp.25.000,- 


\section{g. BSM Tabungan Pensiun}

BSM tabungan pensiun adalah tabungan berupa mata uang rupiah dengan menerapkan akad mudharabah mutlaqah, yang setiap saat dapat dilakukan penarikan sesuai ketentuan dan syarat-syarat yang disepakati. Produk tabungan ini terwujud dari hasil kerjasama antara pihak BSM dengan PT. Taspen bagi para pensiunan pegawai negeri, yang dikelola dengan prinsip mudharabah mutlaqah dan bagi hasil bersaing.

h. BSM Deposito

BSM Deposito merupakan investasi dengan akad mudharabah muthlaqah yang diperuntukan bagi perorangan ataupun non-perorangan yang memiliki jangka waktu tertentu.

Manfaat :

1) Dana nasabah aman dan terjamin karena dikelola secara syariah.

2) Nasabah memperoleh bagi hasil yang kompetitif dan dapat dijadikan jaminan pembiayaan.

3) Fasilitas lain berupa Automatic Roll Over.

Persyaratan :

1) Perorangan : KTP/SIM/Paspor nasabah.

2) Perusahaan : KTP Pengurus, Akte Pendirian, SIUP \& NPWP.

Karakteristik :

1) Fleksibelitas dalam jangka waktu 1, 3, 6 dan 12 bulan.

2) Pencairan dapat dilakukan pada saat telah jatuh tempo.

3) Setoran awal minimum Rp.2.000.000,-

4) Biaya materai Rp6.000.

i. BSM Giro

BSM Giro yaitu sarana penyimpanan dana masyarakat melalui akad wadi'ah yad dhamanah untuk memberikan kemudahan transaksi.

Manfaatnya :

1) Jaminan keamanan bagi dana nasabah dan tersedia setiap waktu.

2) Memberikan kemudahan dalam bertransaksi dengan cek/BG.

3) Fasilitas dalam kecepatan bayar inkaso (kliring antar wilayah) melalui Intercity Clearing.

4) BSM Card memberikan fasilitas berupa kartu ATM dan debet (untuk perorangan).

5) Pengiriman account statement dapat dilakukan pada setiap awal bulan.

6) Kebijakan BSM memberikan bonus yang bersifat bulanan. 
Persyaratan:

1) Perorangan: KTP/SIM/Paspor nasabah.

2) Perusahaan: KTP Pengurus, Akte Pendirian, SIUP \& NPWP.

Karakteristik :

1) Menerapkan prinsip syariah melalui akad wadi' ah yad dhamanah.

2) Setoran awal minimum Rp.500.000,- (perorangan) \& Rp.1.000.000,- (perusahaan).

3) Saldo minimum Rp.500.000,- (perorangan) \& Rp.1.000.000,- (perusahaan).

4) Besaran biaya administrasi bulanan bagi perorangan Rp.10.000,- sedangkan untuk perusahaan Rp.15.000,-

5) Biaya tutup rekening Rp.30.000,-

6) Besaran biaya administrasi atas buku cek/BG senilai Rp.100.000,-

2. Produk Pembiayaan (Penyaluran Dana)

Penyaluran dana yaitu suatu aktivitas yang penting dalam bank syariah. Bank syariah memperoleh pendapatan (return) atas dana yang disalurkan, melalui:

a. BSM Griya

Pembiayaan Griya BSM yaitu pembiayaan dalam jangka pendek, menengah, ataupun panjang yang dperuntukan membiayai belanja keperluan rumah tinggal (konsumer), baik berupa barang baru ataupun second, dilingkungan developer dengan sistem murabahah.

Karakteristik:

1) Biaya angsuran tetap dari awal pembiayaan hingga jatuh tempo.

2) Proses permohonan dilakukan secara cepat dan mudah.

3) Fleksibelitas dalam pembelian rumah baru ataupun second.

4) Maksimum plafond pembiayaan Rp.5 Milyar.

5) Jangka waktu pembiyaan yang panjang.

6) Dalam tabungan BSM difasilitasi berupa autodebet.

Persyaratan :

1) WNI cakap hukum.

2) Terdapat ketentuan usia minimal 21 tahun dan maksimal 55 tahun di saat jatuh tempo dalam pembayaran.

3) Ketentuan besaran dalam angsuran tidak melebihi $40 \%$ yang terhitung dari penghasilan bersih pada setiap bulannya.

4) Fasilitas atas unit yang belum selesai dibangun dapat diberikan pembiayaan yang pertama.

5) Pencairan atas pembiayaan progress pembangunan telah mencapai 50\%, maka 
diberikan total pencairan maksimal sebesar $50 \%$.

6) Pencairan atas unit yang belum selesai dibangun, harus melalui perjanjian kerjasama antara developer dan BSM Kantor Pusat.

b. BSM Cicilan Emas

BSM memfasilitasi nasabah melakukan pembelian emas batangan secara mudah dan menguntungkan. Pembiayaan menggunakan akad Murabahah. Pengikatan agunan menggunakan akad Rahn.

Uang Muka:

1) Pembiayaan minimal $20 \%$ dari nilai atau harga perolehan emas.

2) Nasabah membayar uang muka yang berasal dari nasabah sendiri (self financing). Persyaratan :

1) WNI cakap umur.

2) Ketentuan usia pegawai minimal 21 tahun sampai dengan 55 tahun.

3) Bagin pensiunan maksimal berusia 70 tahun pada waktu pembayaran jatuh tempo.

4) Bagi profesional dan wiraswasta, maka ketentuan maksimal diusia 60 tahun.

5) Fotokopi kartu identitas.

c. BSM Otomotif (OTO)

BSM OTO merupakan pembiayaan atas pembelian kendaraan berupa mobil baru dengan sistem murabahah. Pembiayaan ini antara lain:

1) Kendaraan berupa mobil.

2) Kondisi kendaraan masih baru dengan jangka waktu pembiayaan hingga 5 tahun.

Syarat dan ketentuan :

1) Pemohon harus memiliki pekerjaan yang tetap atau pendapatan tertentu.

2) Usia nasabah pemohon minimal 21 tahun dan maksimal 55 tahun pada saat jatuh tempo.

3) Pengajuan dapat dilakukan secara kolektif atau sendiri-sendiri yang dikoordinir oleh instansi pemohon.

Dokumen-dokumen yang diperlukan :

1) Fotokopi identitas KTP atau SIM.

2) Fotokopi kartu keluarga.

3) Surat keterangan pejabat yang berwenang dari instansi pemohon sebagai keterangan bahwa pemohon benar-benar bekerja di tempat tersebut.

4) Fotokopi surat nikah (bagi pemohon yang sudah menikah) 
5) Slip gaji pemohon yang disahkan oleh instansi pemohon bekerja.

6) Keterangan kendaraan bermotor yang dibeli, yaitu jenis kendaraan, tahun motor, foto copy $\mathrm{BPKB}$, nama pembeli sebelumnya dan keterangan harga kendaraan.

3. Produk Pelayanan Jasa Bank

Produk ini diberikan dalam rangka memenuhi kebutuhan nasabah menjalankan aktivitasnya. Berikut produk-produk pelayanan jasa yang dimaksud, antara lain:

a. BSM Card

Jenis BSM ini merupkan kartu debit yang dikeluarkan oleh BSM. Kartu ini dapat digunakan melalui mesin Electronic Data Capture (EDC) dan Automatic Teller Machine (ATM) untuk melakukan pembayaran tagihan dan belanja.

b. BSM Sentra Bayar

BSM ini merupakan suatu layanan yang diberikan oleh pihak bank dalam menerima pembayaran tagihan nasabah. BSM Sentra Bayar memfasilitasi penarikan tunai, autodebet, SMS Banking, ATM BSM, dan tanda bukti pembayaran.

c. BSM SMS Banking

BSM SMS banking adalah suatu produk layanan yang difasilitasi oleh bank berbasis teknologi seluler untuk memberikan kemudahan dalam bertransaksi, serta pendaftaran gratis di seluruh cabang BSM dan biaya transaksi murah. Produk layanan ini bermanfaat atas kemudahan dalam bertransaksi kapan dan dimana saja.

d. BSM Mobile Banking

Transaksi dalam perbankan dapat ditempuh oleh nasabah melalui handphone yang memanfaatkan jaringan data internet untuk mengkoneksikan mobile banking.

e. BSM Net Banking

Layanan BSM Net Banking dalam melakukan transaksi dapat diakses oleh nasabah melalui jaringan internet di https://bsmnet.syariahmandiri.co.id.

f. Pembayaran Pemindahbukuan ATM (PPBA)

Layanan pembayaran institusi, seperti asuransi, lembaga pendidikan, lembaga keuangan non-bank dan sebagainya dapat dilakukan dengan memilih menu pemindahbukuan di ATM. Layanan pembayaran ini menggunakan akad wakalah wal ujrah, yaitu pemindahan kewenangan secara perwakilan (Wakalah) dari pihak bank ke nasabah untuk melakukan pembayaran dan tagihan. Adapun jasa yang telah diberikan bank, maka pihak bank memperoleh upah (Ujrah). 


\section{g. BSM Jual Beli Valas}

BSM memfasilitasi pertukaran mata uang rupiah yang dilakukan oleh nasabah dengan mata uang asing, atau pertukaran mata uang asing suatu Negara dengan mata uang asing Negara lainnya melalui BSM jual beli valas.

\section{Mekanisme Produk Tabungan BSM dengan Akad Mudharabah Muthlaqah}

Di ketentuan UU No. 10 Tahun 1998 yang mulanya UU No. 7 Tahun 1992 tentang Perbankan bahwa tabungan merupakan suatu simpanan dengan ketentuan syarat yang disepakati untuk melakukan penarikan, tetapi penarikannya bukan berupa cek, bilyet giro, atau dengan alat lain yang sama dengan itu.

1. Mekanisme pembukaan rekening tabungan BSM

Dalam pembukaan rekening tabungan, setoran pertama pada masing-masing bank memiliki perbedaan sesuai dengan kebijakan bank. Pada tabungan BSM, setoran awal Rp.80.000 akan mendapatkan kartu ATM dan buku tabungan yang dapat digunakan pada ATM Bank Mandiri dimanapun berada, dan selanjutnya setoran minimal sebesar Rp.10.000. Minimal saldo yang mengendap dalam rekening Rp.50.000. Adapun mekanisme pembukaan rekening tabungan BSM antara lain:

a. Calon nasabah datang langsung ke kantor BSM KCP Cirebon Siliwangi kemudian menghubungi customer service.

b. Customer service menjelaskan hal-hal yang terkait dengan tabungan BSM dan syaratsyarat yang harus dilengkapi oleh nasabah.

c. Setelah nasabah memperoleh penjelasan informasi dari oleh customer service, dan calon nasabah telah memutuskan untuk menjadi nasabah serta bersedia untuk menjadi penabung tabungan BSM, selanjutnya nasabah melengkapi dan menandatangani formulir yang disediakan oleh BSM KCP Cirebon Siliwangi.

d. Setelah nasabah mengisi formulir dengan lengkap, kemudian formulir tersebut akan diperiksa dan diinput oleh customer service.

e. Nasabah menyerahkan identitas diri (KTP).

f. Nasabah mengisi slip setoran awal sebagai membuka rekening tabungan BSM.

2. Mekanisme Penyetoran tabungan BSM

Penyetoran tabungan BSM dapat dilakukan di seluruh kantor BSM sesuai jam kerja. Mekanisme penyetoran tabungan BSM antara lain:

a. Nasabah mendatangi pihak BSM dengan membawa buku tabungan.

b. Nasabah mengisi slip penyetoran pada kolom yang sudah disediakan. 
c. Buku tabungan nasabah, slip setoran, dan uang diserahkan kepada teller.

d. Setelah teller menerima buku tabungan nasabah, slip setoran, dan uang yang hendak disetor, maka teller akan mengecek tanggal, jumlah uang yang akan disetorkan dengan yang ada pada slip penyetoran serta memeriksa keaslian uang.

e. Teller akan menginput dalam computer, kemudian slip penyetoran akan divalidasi dan stempel serta di paraf oleh teller.

f. Buku tabungan serta slip penyetoran dikembalikan kepada nasabah

g. Slip setoran lembar pertama defile oleh teller sebagai lampiran.

\section{Mekanisme Penarikan Tabungan BSM}

Untuk penarikan tunai diloket teller nasabah harus datang ke kantor Bank Syariah Mandiri, penarikan tabungan harus menggunakan slip penarikan yang tersedia dengan menunjukan buku tabungan. Akan tetapi, jika penarikan melalui BSM Card dapat maka penarikan tersebut dapat dilakukan selama 24 jam pada semua mesin ATM Mandiri Syariah, ATM Mandiri, ATM bersama. Mekanisme penarikan tabungan dengan menggunakan buku tabungan antara lain:

a. Nasabah datang ke kantor BSM.

b. Nasabah harus mengisi slip penarikan tunai yang ditandatangani, dan menyerahkan slip penarikan tunai dan buku tabungan kepada teller pada saat penarikan.

c. Teller akan menggesekkan kartu ATM di mesin EDC.

d. Selanjutnya teller menginput pada computer, kemudian slip penarikan divalidasi serta di paraf oleh teller.

e. Teller akan menghitung uang dihadapan nasabah, kemudian Teller menyerahkan uang tersebut beserta buku tabungan kepada nasabah dan slip sebagai bukti penarikan atas transaksi.

4. Penutupan rekening tabungan BSM

Biaya penutupan rekening tabungan BSM adalah Rp.20.000. Adapun mekanisme dalam penutupan rekening di BSM antara lain:

a. Pihak nasabah mendatangi Bank dimana nasabah membuka rekening tabungan.

b. Nasabah menghubungi customer service, kemudian memberikan alasan tentang keinginannya untuk menutup rekeningnya.

c. Kemudian customer service akan meminta buku tabungan, ATM dan KTP serta memberikan kepada nasabah berupa formulir untuk menutup rekening tabungannya di BSM, serta menandatanginya.

d. Formulir yang diisi dan ditandatangani nasabah akan diserahkan kepada teller untuk 
diverifikasi.

e. Setelah diverifikasi oleh teller, teller akan memberitahu kepada nasabah mengenai sisa saldo yang dapat diambil oleh nasabah.

f. Slip penarikan diisi oleh nasabah sesuai saldo yang tersisa yang bisa diambil, kemudian diserahkan kepada teller.

g. Kemudian teller akan mencocokan tanda tangan pada slip dengan tanda tangan penabung, kemudian di input data penutup nasabah pada komputer.

5. Mekanisme penggantian buku tabungan yang hilang

Biaya penggatian buku tabungan yang rusak atau hilang Rp.10.000, sedangkan penggantian BSM Card Rp.15.000. Adapun mekanisme penggantian buku tabungan dan BSM Card, sebagaimana hasil wawancara penulis bersama Bapak Bahtiar selaku customer service BSM KCP Cirebon Siliwangi pada tanggal 7 Oktober 2019, antara lain sebagai berikut:

a. Nasabah membuat surat kehilangan buku tabungan ke kantor polisi terdekat.

b. Nasabah datang ke Bank Syariah Mandiri.

c. Nasabah menemui customer service untuk melaporkan kehilangan buku tabungan.

d. Nasabah menyerahkan surat laporan kehilangan dari kepolisian dan kartu identitas.

e. Setelah customer service menerima surat kehilangan, maka customer service akan menutup nomor rekening yang lama agar tidak disalahgunakan oleh pihak yang bertanggung jawab dan akan menerbitkan buku tabungan baru serta nomor rekening baru.

Tabungan BSM menerapkan prinsip mudharabah muthlaqah berupa investasi yang terletak pada suatu kerjasama antara pihak shohibul maal dan mudharib, dari investasi tersebut bank akan mendapat untung, dan keuntungannya akan dibagikan kepada nasabah. Bagi hasil merupakan proporsi pembagian hasil dari keuntungan dana nasabah yang di investasikan oleh bank sesuai dengan porsi yang disepakati. Dalam teori lain, ekonomi Islam menentukan sistem bagi hasil untuk menjamin adanya keadilan dan menghapus ekploitasi terhadap pihak lain. Dengan demikian, inti mekanisme bagi hasil terdapat dalam kerjasama yang baik antara pihak pemodal dengan pengelola usaha, sehingga terwujud suatu kerjasama yang baik sebagai karakter dalam ekonomi Islam melalui akad qiradh atau mudharabah (Ascarya, 2013). Istilah mudharabah dipopulerkan oleh orang-orang di Irak, sebab ada bagian berupa laba bagi setiap pihak yang melakukan akad, atau pengusaha berproses dalam mengusahakan harta modal tersebut, sedangkan orang-orang di daerah Hijaz menyebut bagian laba tersebut dengan istilah qiradh (Firdaweri, 2014).

Dalam pelaksanaan tabungan BSM sesuai dengan prinsip mudharabah muthlaqah yang mana tabungan ini merupakan pendanaan dari masyarakat kepada bank kemudian dana 
tersebut digunakan BSM sebagai penyedia pembiayaan bagi calon nasabah yang diperuntukan sebagai modal kerja yang sesuai dengan prinsip syariah.

\section{KESIMPULAN}

Berdasarkan uraian di atas, dapat ditarik dua kesimpulan, yaitu pertama, terdapat tiga jenis produk Bank Syariah Mandiri (BSM) yang sampai saat ini masih beroperasi, yaitu penghimpunan dana, pembiayaan (penyaluran dana), dan pelayanan jasa. Dan kedua, tabungan BSM yaitu tabungan berupa mata uang rupiah, dan bersifat harian. Rekening ini berdasarkan sistem akad mudharabah muthlaqah dengan melalui alur, yaitu pembukaan rekening tabungan, penyetoran tabungan BSM dapat dilakukan diseluruh kantor BSM sesuai ketentuan jam buka kas, penarikan tunai diloket teller nasabah harus datang ke kantor BSM, penutupan rekening tabungan BSM dilakukan dengan mengisi formulir yang disediakan, dan penggantian buku tabungan yang saja hilang dapat dilakukan dengan membuat surat-surat kehilangan di kantor kepolisian terdekat kemudian menyerahkannya kepada customer service.

\section{UCAPAN TERIMA KASIH}

Ucapan terima kasih kami tujukan kepada segenap jajaran BSM KCP Siliwangi Cirebon. Besar harapan, semoga hasil penelitian ini mampu berkontribusi memberikan manfaat untuk masyarakat luas.

\section{DAFTAR PUSTAKA}

Ascarya. (2013). Akad dan Produk Bank Syariah. Rajawali Pers.

Emzir. (2012). Metodologi Penelitian Kualitatif Analisis Data. Jakarta: Raja Grafindo Persada.

Firdaweri, F. (2014). PERIKATAN SYARI'AH BERBASIS MUDHARABAH (TEORI DAN PRAKTIK). Asas.

Ismail. (2011). Perbankan Syariah. Jakarta: Kencana Prenada Media Group.

Moleong, L. J. (1997). Metodologi Penelitian Kualitatif. Bandung: PT Remaja Rosda Karya.

Narbuko, C., \& Ahmadi, A. (2007). Metodologi Penelitian. Jakarta: Bumi Aksara.

Nasution, S. (2005). Metode Penelitian Naturalistik Kualitatif. Bandung: Tarsito.

Sugiyono. (2016). Memahami Penelitian Kualitatif. Bandung: Alfabeta.

Wanto, M. (2014). Implementasi Akad Produk Tabungan Rencana di PT. Bank Syariah Mega Indonesia Gallery Cianjur. Muqtasid: Jurnal Ekonomi Dan Perbankan Syariah. https://doi.org/10.18326/muqtasid.v5i1.75-97. 